SJ Quinney College of Law, University of Utah Utah Law Digital Commons

Utah Law Faculty Scholarship

Utah Law Scholarship

$11-2017$

\title{
Choosing Corporations Over Consumers: The Financial Choice Act of 2017 and the CFPB
}

Christopher L. Peterson

S.J. Quinney College of Law, University of Utah, chris.peterson@law.utah.edu

Follow this and additional works at: https://dc.law.utah.edu/scholarship

Part of the Consumer Protection Law Commons

\section{Recommended Citation}

Peterson, Christopher L., "Choosing Corporations Over Consumers: The Financial Choice Act of 2017 and the CFPB" (2017). Utah Law Faculty Scholarship. 72.

https://dc.law.utah.edu/scholarship/72 


\title{
Choosing Corporations Over Consumers: THe FinANCIAL CHOICE ACT OF 2017 AND THE CFPB
}

\author{
Christopher L. Peterson
}

\begin{abstract}
I. INTRODUCTION
The track record of the Consumer Financial Protection Bureau ("CFPB") is a continuing focal point in national political debates. Critics of the agency have argued that the Bureau lacks accountability and has been too aggressive in its rulemaking, supervisory, and enforcement programs. Defenders of the agency argue that the Bureau's work benefits millions of Americans while preserving access to credit and that the agency is a positive example of government leadership. In the first year of the Trump administration, this national conversation has coalesced around H.R. 10, the proposed Financial Choice Act of 2017 (“Choice Act"), ${ }^{1}$ sponsored by House Financial Services Committee Chairman Jeb Hensarling and supported by President Donald J. Trump. The Choice Act substantially amends or repeals many of the reforms adopted in the Dodd-Frank Wall Street Reform and Consumer Protection Act ${ }^{2}$ "Dodd-Frank Act") after the financial collapse of 2008 and ensuing Great Recession. While the proposed Choice Act addresses a variety of banking and financial industry issues, Title VII of the bill focuses on the CFPB. The proposed legislation would rename the CFPB the "Consumer Law Enforcement Agency" and dramatically curtail the agency's legal authorities in a variety of ways. The Choice Act would, for example: eliminate the CFPB's supervisory authority, ${ }^{3}$ repeal the Dodd-Frank Act's prohibition of "unfair, deceptive, or abusive acts or practices" in consumer finance, ${ }^{4}$ and eliminate the CFPB's independent source of funding. ${ }^{5}$

To inform discussion of the Financial Choice Act in particular and consumer financial policy making more generally, there is an ongoing need for descriptive empirical analysis of the CFPB's law enforcement track record. This article presents an analysis classifying all of the CFPB's publicly announced enforcement actions from the agency's inception through the end of the 2016 calendar year. Moreover, this article also analyzes how the Financial Choice Act would have affected these CFPB enforcement actions if it had been controlling law in recent years. Thus, this study asks a hypothetical question: If the Choice Act were the law of the United States from 2012 to 2016, how would the CFPB's enforcement track record have changed? Answers to this question
\end{abstract}

* John J. Flynn Professor of Law, University of Utah, S.J. Quinney College of Law. This Article draws on remarks given and helpful feedback received at the 2017 Fisher Memorial Program of the American Bar Association Business Law Section's Consumer Financial Services Committee. This research was made possible, in part, through generous support from the Albert and Elaine Borchard Fund for Faculty Excellence at the University of Utah. Michael Harmond provided valuable research assistance.

1 See Financial Choice Act of 2017, H.R. 10, 115th Cong. (2017).

2 Dodd-Frank Wall Street Reform and Consumer Protection Act, Pub. L. No. 111-203, 124 Stat. 1376 (2010) (codified as amended in scattered sections of 7, 12, 15, 22, 31, and 42 U.S.C.) (hereinafter the "Dodd-Frank Act").

${ }^{3}$ H.R. 10, $\$ 727$.

${ }^{4} I d$. at $\ 711(\mathrm{a})$.

${ }^{5} \mathrm{I} d$. at $\$ 713$. 
may assist the U.S. Senate in its deliberations over whether to follow the lead of Representative Hensarling and President Trump. More generally, this study can help inform policy makers, practicing attorneys, scholars, the press, and students of consumer finance on what the future may hold if Congress adopts the Financial Choice Act. This study also holds a mirror to the CFPB itself, illustrating the political resistance that has emerged to the Bureau's law enforcement work.

Part II of this article briefly summarizes the CFPB's supervisory, fair lending, and enforcement authorities under the Dodd-Frank Act and then reviews the Choice Act's proposed changes to this authority. Part III explains the study's methodology, Part IV reports and analyzes results, and Part $\mathrm{V}$ provides a brief conclusion.

\section{BACKground: Proposed Changes TO CFPB UNDER THE FINANCIAL CHOICE ACT OF 2017}

In 2008 the American banking industry collapsed causing 11 trillion dollars in wealth to vanish and leaving 21 million Americans without work. ${ }^{6}$ Over 9 million homes were lost to foreclosure or short sales. ${ }^{7}$ The Great Recession caused profound health and welfare consequences hurting millions of Americans in all fifty states. Illadvised consumer finance led to greater homelessness, hunger, disease, and suicide. ${ }^{8}$ Congress responded to this national crisis with the Dodd-Frank Act which, among other reforms, established the Consumer Financial Protection Bureau. ${ }^{9}$ Structurally, the CFPB is an independent agency housed within the Federal Reserve Board. Instead of funding the CFPB through the congressional appropriations process, the Dodd-Frank Act provided that the Fed must, at the CFPB's request, transfer to the CFPB an inflation-adjusted sum equal to $12 \%$ of the Federal Reserve's 2009 annual operating expenses. ${ }^{10}$ The Fed gathers its own funding through its operations which include collecting interest on U.S. Treasury bonds and foreign currency investments held by the system through its open market operations, fees received for services provided, such as operation of the Automated Clearinghouse ("ACH") system, and interest on loans made to banks through the "discount window." 11 Congress tasked the CFPB with protecting Americans from harmful consumer financial practices. To fulfill this mission,

${ }^{6}$ U.S. FIN. CRISIS INQUIRY COMM’N, FIN. CRISIS INQUIRY REPORT, at xv (2011).

${ }^{7}$ Laura Kusisto, Many Who Lost Homes to Foreclosure in Last Decade Won't ReturnNAR, WALL STREET J. (Apr. 20, 2015, 12:50 PM), http://www.wsj.com/articles/many-who-lost-homes-to-foreclosure-in-last-decadewont-return-nar-1429548640.

8 See Christopher L. Peterson, Consumer Financial Protection Bureau Law Enforcement: An Empirical Review, 90 Tulane L. REV. 1057, 1059-60 (2016) (hereinafter CFPB Empirical Review) (collecting empirical research).

${ }_{9}^{9}$ Dodd-Frank Wall Street Reform and Consumer Protection Act, Pub. L. No. 111-203, 124 Stat. 1376, tit. X (2010) (codified at 12 U.S.C. SS 5481 et seq.). Congress entitled Title X of the Dodd-Frank Act which establishes the CFPB, the Consumer Financial Protection Act. 12 U.SC. $\int 5491($ a).

${ }^{10} I d$. at $\int 5497($ a) (1)-(2).

${ }^{11}$ Federal Reserve Board of Governors, Frequently Asked Questions: What does it Mean that the Federal Reserve is "independent" within the government"?, (March 1, 2017), https://www.federalreserve.gov/faqs/about_12799.htm.

\section{- Working Draft•}


Congress authorized the Bureau "to administer, enforce, and otherwise implement the provisions of Federal consumer financial law."12

Organizationally, Congress authorized the Bureau to establish a variety of offices and legal authorities within the CFPB. First, the CFPB established a consumer response office to respond to consumer complaints and inquiries regarding financial services businesses. ${ }^{13}$ The CFPB's Consumer Response office maintains a web-based and telephone intake portal that handles over some quarter-million inquiries in over 180 languages each year. ${ }^{14}$ The Dodd-Frank Act required the creation of several consumer education and empowerment offices within the CFPB. These offices include: a financial education office, ${ }^{15}$ an office for providing information, guidance, and technical assistance on providing financial services to traditionally underserved communities, ${ }^{16}$ an office focused on the financial protection of older Americans, ${ }^{17}$ the office of a private student lending ombudsman, ${ }^{18}$ and an office of military service member affairs. ${ }^{19}$ The CFPB also has an Office of Regulations which is responsible for exercising the Bureau's rulemaking authority under consumer financial laws. Consumer financial laws are defined to include Title X of the Dodd-Frank Act itself, as well as a list of enumerated consumer financial protection law that include the Truth in Lending Act, the Fair Debt Collection Practices Act, the Fair Credit Reporting Act, and others. ${ }^{20}$

1212 U.S.C. $\int 5512(\mathrm{a})$.

13 See id. at $\int 5534$ (establishing consumer complaint response authorities and responsibilities).

14 Financial Report of the Consumer Financial Protection Bureau: FISCAL YEAR 2016, 23 (November 15, 2016).

15 See 12 U.S.C. $\int 5493(\mathrm{~d})$.

${ }^{16} I d$. at $\int 5493(\mathrm{~b})(2)$.

${ }^{17} \mathrm{Id}$. at $\int 5493(\mathrm{~g})$.

${ }^{18} I d$. at $\int 5535$.

${ }^{19} I d$. at $\int 5493(\mathrm{e})$.

${ }^{20}$ Id. $\int 5511$. The enumerated consumer laws include: The Alternative Mortgage Transaction Parity Act of 1982, Public L. No. 97-320, 96 Stat. 1545 (codified as amended at 12 U.S.C. ch. 39); The Consumer Leasing Act of 1976, Pub. L. No. 94-240, 90 Stat. 257 (codified as amended at 15 U.S.C. JS 1667-1667f); The Electronic Fund Transfer Act, Pub. L. No. 90-321, 92 Stat. 3728 (codified as amended at 15 U.S.C. ch. 41, subch. 6); The Equal Credit Opportunity Act, Pub. L. No. 90-321, 88 Stat. 1521 (codified as amended at 15 U.S.C. ch. 41, subch. 4); The Fair Credit Billing Act, Pub. L. No. 93-495, 88 Stat. 1511 (codified as amended at 15 U.S.C. ch. 41, subch. 1, pt. D); The Fair Credit Reporting Act, Pub. L. No. 90-321, 84 Stat. 1128 (codified as amended at 15 U.S.C. ch. 41, subch. 3) (excluding $\iint$ 615(e), 628, 15 U.S.C. $\iint 1681 \mathrm{~m}(\mathrm{e}), 1681 \mathrm{w}$ ); The Home Owners Protection Act of 1998, Pub. L. No. 105-216, 112 Stat. 897 (codified as amended at 12 U.S.C. ch. 49); The Fair Debt Collection Practices Act, Pub. L. No. 90-321, 91 Stat. 874 (codified as amended at 15 U.S.C. ch. 41, subch. 5); Federal Deposit Insurance Act $\int 43(\mathrm{~b})-(\mathrm{f}), 64$ Stat. 873, (codified as amended 12 U.S.C.

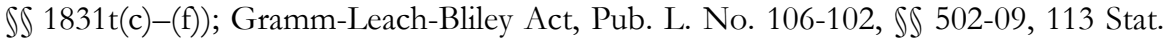
1338, (codified as amended at 15 U.S.C. $\iint$ 6802-6809) (excluding $\int 505$ as it applies to $\int$ 501(b)); The Home Mortgage Disclosure Act of 1975, Pub. L. No. 94-200, 89 Stat. 1125 (codified as amended at 12 U.S.C. ch. 29); The Home Ownership and Equity Protection Act of 1994, Pub. L. No. 103-325, 108 Stat. 2190 (codified as amended in scattered sections of 15 U.S.C. ch. 41); The Real Estate Settlement Procedures Act of 1974, Pub. L. No. 93-533, 88 Stat. 1724 (codified as amended at 12 U.S.C. ch. 27); The

\section{- Working Draft•}


Borrowing from the much older Federal Trade Commission Act, Congress also gave the CFPB enforcement and rulemaking authority to identify and stop any "unfair or deceptive acts or practices" as well as adding a new category of "abusive" acts or practices. ${ }^{21}$ While the prohibition of abusive financial acts or practices was controversial, as an empirical matter, the CFPB's law enforcement staff have overwhelmingly focused on identifying and stopping deceptive consumer financial practices that are likely to mislead reasonable consumers about a material aspect of the service. ${ }^{22}$

The CFPB's law enforcement responsibilities are implemented through the Bureau's Supervision, Enforcement and Fair Lending Division (SEFL). The Bureau supervises large banks and credit Unions with over $\$ 10$ billion in assets, as well as other supervised non-bank consumer finance business specified by Congress or Bureau regulations. ${ }^{23}$ Supervised consumer finance companies include mortgage originators, brokers, servicers, and foreclosure assistance providers; private student loan originators and student loan servicers; ${ }^{24}$ and payday lenders; ${ }^{25}$ as well as large consumer reporting agencies, ${ }^{26}$ debt collection businesses, ${ }^{27}$ international remittance providers, ${ }^{28}$ and automobile finance companies. ${ }^{29}$ CFPB supervisory staff conducts risk-based, confidential examinations that audit supervised business to ensure compliance with consumer financial protection laws. Several hundred CFPB examiners regularly travel throughout the country visiting consumer financial businesses to conduct exams on sight. ${ }^{30}$ The Bureau's supervisory staff publishes an examination manual to assist

S.A.F.E. Mortgage Licensing Act of 2008, Pub. L. No. 110-289, 122 Stat. 2810 (codified as amended at 12 U.S.C. ch. 51); The Truth in Lending Act, Pub. L. No. 90-321, 82 Stat. 146 (codified as amended at 15 U.S.C. ch. 41, subch. 1); The Truth in Savings Act, Pub. L. No. 102-242, 105 Stat. 2334 (codified as amended at 12 U.S.C. ch. 44); Omnibus Appropriations Act, 2009, Pub. L. No. 111-8, \ 626, 123 Stat. 524, 678-79 (codified as amended at 15 U.S.C. \1638); and The Interstate Land Sales Full Disclosure Act, Pub. L. No. 90-448, 82 Stat. 590 (codified as amended at 15 U.S.C. ch. 42). Also, Congress subsequently gave the CFPB enforcement authority under the Military Lending Act. Pub. L. No. 109-34, 120 Stat. 2266 (codified as amended at 10 U.S.C. \ 987, 15 U.S.C. \$1607). However, the Department of Defense retains rulemaking authority for this statute. Id. \987(h).

21 12 U.S.C. SS 5531, 5536.

22 Peterson, CFPB Empirical Review, supra note 8, at 1093 (finding that in CFPB enforcement cases through 2015 over $90 \%$ of all consumer relief was awarded in cases in which the CFPB uncovered evidence that defendants illegally deceived customers).

${ }^{23} I d$. at $\iint 5514,5515$.

${ }^{24}$ Id. $\int 1090.106$.

${ }^{25} I d$. at $\int 5514(\mathrm{a})$.

2612 C.F.R. $\int 1090.104$.

${ }^{27}$ Id. $\int 1090.105$.

${ }^{28}$ Id. $\int 1090.107$.

${ }^{29}$ Id. $\int 1090.108$.

30 See Consumer Financial Protection Bureau, CFPB Supervision AND EXAMINATION MANUAL, at Overview 10-13 (March 2017), https://s3.amazonaws.com/files.consumerfinance.gov/f/documents/201706_cfpb_s upervision-and-examination-manual.pdf (for an overview of the CFPB's examination process).

\section{- Working Draft•}


companies in preparing for exams, and regular Supervisory Highlights reports sharing public results of the examiners' work. ${ }^{31}$

Congress also created the CFPB's Office of Fair Lending and Equal Opportunity, which is housed within the Bureau's SEFL division. ${ }^{32}$ This office is responsible for providing oversight and enforcement of consumer financial laws that ensure equitable and nondiscriminatory access to credit including in particular the Equal Credit Opportunity Act. ${ }^{33}$

The Bureau enforces other consumer financial laws through an Office of Enforcement which investigates and pursues enforcement actions against businesses and individuals governed by consumer financial laws. The Bureau has enforcement jurisdiction over any covered person or service provider to a covered person, except for small banks and credit unions, automobile dealers that do not routinely engage in "buy-here, pay-here" financing, and a short list of other specifically excluded businesses. ${ }^{34}$ Congress authorized the Bureau to enforce federal consumer financial laws either through administrative enforcement procedures or through its own authority to litigate in federal court. ${ }^{35} \mathrm{CFPB}$ administrative enforcement actions are conducted under a CFPB regulation that largely mirrors other administrative enforcement agencies, with trials before an administrative law judge and decisions reviewable on appeal to the Bureau's Director. ${ }^{36}$ Congress also authorized the Bureau to bring enforcement actions in Federal court independent of the Department of Justice. ${ }^{37}$ In both administrative proceedings and civil litigation, the CFPB is entitled to seek any appropriate legal or equitable relief including restitution, disgorgement, and civil money penalties. ${ }^{38}$

The proposed Financial Choice Act of $2017^{39}$ would substantially revise and repeal much of the Dodd-Frank Act. Among many changes, the Choice Act would repeal Dodd-Frank's orderly liquidation authority provisions and eliminate the stress testing and emergency planning requirements for many of the largest financial institutions. With respect to the CFPB, the Choice Act would eliminate or restrict many of the Bureau's powers, offices, and authorities. Initially, the Choice Act appears to embrace and prioritize the CFPB's law enforcement mission by renaming the CFPB the

31 See Consumer Financial Protection Bureau, CFPB Supervision And EXAMINATION MANUAL, (March 2017), https://s3.amazonaws.com/files.consumerfinance.gov/f/documents/201706_cfpb_s upervision-and-examination-manual.pdf; Consumer Financial Protection Bureau, Supervisory Highlights, Issue 15, Spring 2017.

3212 U.S.C. $\int 5493(\mathrm{c})$.

${ }^{33} I d$. at $₫ 5493(\mathrm{c})(2) ; 15$ U.S.C. $\int 1691$.

3412 U.S.C. $\iint 5515(\mathrm{a}),(\mathrm{c})$; $\int 5516(\mathrm{a})$, (d). Unless they are acting as a service provider to a covered person, other businesses explicitly excluded from CFPB enforcement authority include nonfinancial retailers of goods or services, real estate brokers, manufactured home retailers, accountants or tax preparers, and, in some circumstances, attorneys. Id. \5517. But See CFPB v. Fredrick J. Hanna \& Assocs., 114 F. Supp. 3d 1342, 1362-70 (N.D. Ga. 2015) (holding debt collection lawsuit mill subject to CFPB jurisdiction under the FDCPA and the Dodd-Frank Act).

35 12 U.S.C. $\iint 5563,5564$.

3612 C.F.R. pt. 1081.

3712 U.S.C. \5564(a) (2012).

${ }^{38}$ Id. $\int 5565(\mathrm{a})(2)$.

${ }^{39}$ Financial Choice Act of 2017, H.R. 10, 115th Cong. (2017).

\section{- Working Draft•}


Consumer Law Enforcement Agency (“CLEA"). ${ }^{40}$ The bill would remove the agency's independent source of funding, subjecting it to annual congressional appropriations and potential future budget cuts. ${ }^{41}$ The bill would also facilitate changes to sub-units within the CFPB by allowing the director of the new CLEA to dissolve and eliminate the various consumer education and empowerment offices focused on particular vulnerable groups, including the Office of Service Member Affairs, the National Student Lending Ombudsman's office, and the Office of Older Americans. The bill also subjects CFPB employees to the federal government's general compensation schedule which would have the effect of imposing significant pay cuts on existing and future staff 90 days after the Act becomes law. ${ }^{42}$

The Choice Act also eliminates the CFPB's research, market monitoring, and publishing authorities. ${ }^{43}$ The bill would prohibit the new agency from making consumers' complaint narratives public. ${ }^{44}$ And the bill creates a new restriction on using private information about consumers stating that " $[\mathrm{t}]$ he Agency may not request, obtain, access, collect, use, retain, or disclose any nonpublic personal information about a consumer" without explicit permission from each consumer. ${ }^{45}$ Unlike private companies, the Federal government does not generally enter into contracts with consumers making the logistics of obtaining permission to gather market data potentially insurmountable. Simultaneously, Title VII of the Choice Act provides no restrictions on the ability of banks or other financial service providers to collect and share data about the public.

Ironically, while limiting the Bureau's ability to gather useful market data the Choice Act simultaneously creates a host of new obligations to conduct empirical studies. the legislation would create a new Office of Economic Analysis ("OEA") within the agency tasked with engaging in cost-benefit analysis of public action. ${ }^{46}$ The Choice Act would require a cost-benefit analysis, and require the Director to consider that analysis, prior to adopting any rule. ${ }^{47}$ The bill would also impose upon the new OEA a constantly revolving docket of periodically scheduled retrospective cost-benefit reviews and public reports on every existing regulation overseen by the agency. ${ }^{48}$ Additionally, the bill requires the Director to issue advisory opinions on request. ${ }^{49}$ But ironically, the legislation would also instruct courts to ignore these advisory opinions by reversing the current law that requires courts to grant deference to the CFPB's interpretation of the laws and regulations it enforces. ${ }^{50}$ With nearly twenty different enumerated consumer financial laws and their related regulations falling within the jurisdiction of the agency, these retrospective analyses and advisory opinions would

${ }^{40} I d$. at $\int 711(\mathrm{a})$.

${ }^{41} I d$. at $\int 713$.

42 Id. at $\int 723$. Currently, on average CFPB employees make "somewhat less than a third-year investment banking analyst." Matt Levine, Are Bank Regulators Overpaid?, BloOmberg VIEW (Apr. 22, 2014, 10:53 AM), http://www.bloombergview.com/articles/2014-04-22/are-bank-regulators-overpaid.

${ }^{43}$ H.R. 10, \ 724 (2017).

${ }^{44} \mathrm{Id}$. at $\int 725$.

${ }^{45} I d$. at $\int 731$.

${ }^{46} \mathrm{Id}$. at $\$ 717$.

${ }^{47} I d$. at $\int 717$.

${ }^{48} I d$. at $\int 717(4)$.

${ }^{49} I d$. at $\int 721$.

${ }^{50} \mathrm{Id}$. at $\int 718$. 
require the expenditure of substantial resources on activities that do not directly benefit victims of illegal practices or provide legal certainty to industry. Moreover, to ensure these ongoing tasks occupy the CLEA's staff time, the legislation also creates a new independent inspector general's office to police the agency. ${ }^{51}$

Although the Choice Act appears to prioritize law enforcement, the bill would erect a variety of procedural hurdles in the path of law enforcement investigations, administrative actions, and federal litigation. For example, the Choice Act would give the new OEA a gatekeeping role in all law enforcement matters. Under the new law, the Agency would be required to conduct a specific cost-benefit study prior to initiating any law enforcement case. ${ }^{52}$ Moreover, the law appears to require a second, separate cost-benefit analysis before resolving any disputed enforcement action with a consent order. ${ }^{53}$ And presumably, the Office of Enforcement within the CLEA would compete for the OEA's cost-benefit analysis resources with the slate of ongoing studies required on all the agency's existing regulations. The bill would also grant defendants in administrative enforcement actions a right to compel the Agency to remove the case to Federal court, thereby limiting the Agency's tactical options. ${ }^{54}$ The bill would also slow down investigations by giving civil investigative demand respondents the right to respond more slowly and to challenge the Agency's right to collect information in Federal court. ${ }^{55}$ The Choice Act also eliminates the common pool of civil money penalty funds that provides consumer relief to victims of insolvent defendants. ${ }^{56}$ Currently, this pool provides thousands of victimized families compensation when the businesses or individuals that hurt them are bankrupt or have hidden their assets. Under the Choice Act, any excess civil money penalties would simply be handed over to Congress while families victimized by insolvent defendants would receive no compensation. ${ }^{57}$

The Choice Act would also eliminate the CFPB's supervisory authority. ${ }^{58}$ Under the Choice Act, the new CLEA would no longer conduct compliance audits of large banks, mortgage brokers, credit reporting agencies, debt collectors, and other businesses currently subject to CFPB supervision. The CFPB schedules its exams by analyzing which businesses present the greatest risk of violating federal consumer protection laws and causing harm to consumers. ${ }^{59}$ Examiners are tasked with helping the industry achieve consistent compliance standards for federal consumer financial laws nationwide. ${ }^{60}$ The Choice Act change would eliminate the CFPB's largest office

${ }^{51} I d$. at $\int 714$.

${ }^{52} I d$. at $\$ 717$.

${ }^{53} \mathrm{Id}$. at $\int 717$.

${ }^{54}$ H.R. 10 at $\int 715$.

${ }^{55} \mathrm{Id}$. at $\int 716$.

${ }^{56} I d$. at $\int 722$. The Choice Act would return undistributed civil money penalties to Congress, instead of providing relief to victims of illegal consumer protection law violations. $I d$.

${ }^{57} \mathrm{Id}$.

${ }^{58} I d$. at $\int 712$.

${ }^{59}$ Consumer Financial Protection Bureau, Supervisory Highlights, Issue 1, at 3, Fall 2012. See also Jean Braucher \& Angela Littwin, Examination as a Method of Consumer Protection, 87 TEMPLE L. REV. 807, 837-40 (2015) (analyzing CFPB's risk-based supervisory policies).

${ }^{60}$ Consumer Financial Protection Bureau, Supervisory Highlights, Issue 1, at 3, Fall 2012.

- Working Draft• 
that houses several hundred compliance examiners that travel the country conducting compliance audits of supervised businesses. ${ }^{61}$ Supervision is one of the key methods through which the CFPB monitors and responds to spikes and trends in industry problems. ${ }^{62}$ Eliminating this supervisory oversight would take away the CFPB's primary method of resolving compliance problems outside of a public, adversarial enforcement action context. Under the Choice Act, the new CLEA would not have access to consumer finance business records unless it was prepared to sue to obtain those records in Federal court. Instead, the Choice Act would return supervisory authority for consumer protection to the banking regulations responsible for supervision prior to the 2008 financial crisis. And for non-bank companies such as debt collectors, credit reporting agencies, and payday lenders, federal compliance exams would simply cease to exist. Thus, while the legislation creates higher hurdles for bringing enforcement cases, it also eliminates the agency's most powerful non-adversarial tool for gathering compliance information necessary to surmount those hurdles.

Substantively, the Choice Act also changes several consumer protection laws. The most far reaching change is the repeal of the Dodd-Frank Act's prohibition of "unfair, deceptive and abusive acts or practices." ${ }_{3}$ The CFPB's law enforcement program has focused more on deterring deception by consumer finance businesses than any other regulatory requirement. ${ }^{64}$ In the first five years of the CFPB's enforcement program, "[d]eception was, by far, the most commonly pleaded claim in CFPB matters." 65 Cases that included a deception claim produced over 90 percent of the consumer relief provided to the American public. ${ }^{66}$ Without the Dodd-Frank Act's prohibition of unfair, deceptive and abusive practices, the new CLEA would not have a law within its jurisdiction that would allow it to challenge even intentional lying by banks or other financial service providers to their customers. As they did before the fiscal crisis, prudential banking regulators would continue to have enforcement authority for unfair and deceptive practices, ${ }^{67}$ but-bizarrely—the new agency specifically tasked with consumer law enforcement would not. ${ }^{68}$

The Choice Act would also eliminate the CFPB's regulatory and enforcement authority over what is arguably the most controversial segment of the consumer finance industry: short-term, high-interest lending. Specifically, the Choice Act would prohibit

61 See Consumer Financial Protection Bureau, CFPB Supervision And ExAMINATION MANUAL, at Overview 10-13 (March 2017), https://s3.amazonaws.com/files.consumerfinance.gov/f/documents/201706_cfpb_s upervision-and-examination-manual.pdf (for an overview of the CFPB's examination process).

${ }^{62}$ Consumer Financial Protection Bureau, Supervisory Highlights, Issue 15, at 25-26, Spring 2017.

${ }^{63}$ H.R. 10, \735(a) ("The Consumer Financial Protection Act of 2010 (12 U.S.C. 5481 et seq.) is amended-

(1) in section 1021(b)(2), by striking 'from unfair, deceptive, or abusive acts and practices ..."').

64 Peterson, CFPB Empirical Review, supra note 8, at 1095.

${ }^{65} \mathrm{Id}$.

${ }^{66} I d$.

67 See Braucher \& Littwin, supra note 59, at 821 (discussing the tension between safety and soundness oversight and consumer protection at prudential banking regulators).

${ }^{68}$ H.R. 10, \§ $735-736$. 
the new Consumer Law Enforcement Agency from enforcing the law "with respect to payday loans, vehicle title loans, or other similar loans." ${ }^{69}$ Payday loans are illegal under the laws of about a dozen states, carry average interest rates of around 400 percent, and are often criticized by consumer advocates as predatory debt traps. ${ }^{70}$ Others view payday loans are a necessary tool for liquidity constrained consumers and believe prohibition of the product would lead to unintended consequences. ${ }^{71}$ The public overwhelmingly supports usury limits that effectively ban the product. ${ }^{72}$ The DoddFrank Act does not allow the CFPB to eliminate payday lending with an interest rate limit, but it does prohibit payday lenders from using unfair, deceptive or abusive marketing, underwriting, or collection tactics. ${ }^{73}$ While the Federal Trade Commission would continue to have jurisdiction over non-bank lenders, under the proposed Choice Act the new Consumer Law Enforcement Agency would not have the authority to bring an enforcement action against a payday lender that intentionally lies about its products or services. The new CLEA would also be powerless to enforce enumerated federal consumer protection laws including the Truth in Lending Act, the Fair Debt Collection Practices Act, the Equal Credit Opportunity Act, and the Fair Credit Reporting Act against payday lenders. Under the Choice Act payday lenders would receive the most favorable, lightly regulated treatment of any consumer financial service provider in America. Collectively, the constraints placed on the CFPB by the proposed Financial Choice Act of 2017 would severely restrain actual law enforcement at the new consumer law enforcement agency.

\section{METHODS}

This study identifies and classifies every public CFPB enforcement case from the inception of the CFPB through the end of the 2016 calendar year. Public CFPB enforcement actions were identified through the CFPB's website, press releases, annual reports to Congress, administrative adjudication docket, and searches of the Bureau's unsealed federal court pleadings. For each case, the CFPB has released some legal

${ }^{69} \mathrm{Id}$. at $\int 733$ ("The Agency may not exercise any rulemaking, enforcement, or other authority with respect to payday loans, vehicle title loans, or other similar loans.").

${ }_{70}$ See Oren Bar-Gill \& Elizabeth Warren, Making Credit Safer, 157 PENN. L. REv. 101, 155-156 (2008); DEP’T OF DEF., REPORT ON PREDATORY LENDING

Practices Directed AT MEMBERs OF THE ARMED ForCES AND THEIR DePENDENTS 39-46 (2006); Christopher L. Peterson, "Warning: Predatory Lender" - A Proposal for Candid Predatory Small Loan Ordinances, 69 WASH. \& LEE L. REV. 893, 928 (2012) (hereinafter Warning: Predatory Lender).

71 Thomas A. Durkin, Gregory Elliehausen, Michael E Staten, \& Todd ZYWICKI, CONSUMER CREDIT AND THE AMERICAN ECONOMY 394-96 (2014); Victor Stango, Are Payday Lending Markets Competitive?, REgulation 26, 33 (Fall 2012)

https://object.cato.org/sites/cato.org/files/serials/files/regulation/2012/11/v35n35.pdf; Todd Zywicki \& Astrid Arca, The Case Against New Restrictions on Payday Lending, 64 MerCATUs on POLICY 1, 2 (2009), https://www.mercatus.org/system/files/MOP64_FMWG_Payday\%20Lending_web. pdf.

72 See Peterson, supra note 70, at 894.

73 See 12 U.S.C. SS 5531, 5536 (explaining that covered persons providing consumer financial products are prohibited from unfair, deceptive or abusive practices).

\section{- Working Draft•}


documentation of the enforcement matter. Typically, these documents include one or more of the following: a notice of charges, a complaint, a consent order, a stipulation consenting to issuance of a consent order, or a settlement agreement. For cases pursued through the CFPB's administrative enforcement procedures, the Bureau's Office of Administrative Adjudication ("OAA") maintains a docket sheet that includes all publicly available pleadings, motions, and orders. For cases in litigation, court filings were accessed as necessary through the publicly available PACER system provided by the U.S. judiciary.

For each of the CFPB's public enforcement matters, these documents were reviewed and coded using over 70 different variables. The data set analyzed in this study updates and expands upon a data set compiled for a previous study reported in the Tulane Law Review. ${ }^{74}$ Coded variables included: the date the Bureau announced each case; the date the case was resolved (if any); whether the case was filed as an administrative enforcement matter or in U.S. district court; whether the case was settled or contested upon announcement; whether the case involved a bank, credit union, or some other non-depository company; whether the Bureau charged an individual defendant with violating the law; and dollar amounts of total consumer redress and civil money penalties awarded in all consent orders, final administrative orders, or judgments imposed in every concluded matter. ${ }^{75}$ This study also classifies every violation of law the CFPB has asserted in public enforcement actions based on the statute providing the legal authority for the claim. These classifications include all 18 enumerated statutes set out in the Dodd-Frank Act, additional law that Congress subsequently added to the Bureau's enforcement jurisdiction, as well as the Bureau's unfair, deceptive, and abusive acts or practices ("UDAAP") authorities. This study also classified the financial product or service involved in each case based on the following categories: credit cards, mortgage loans, student loans, automobile purchase loans, nonauto retail finance, deposit accounts, remittances, pawn credit, payday loans (including similar small installment loans and car title lending), medical debt, and payment processing services.

Furthermore, this study adds a new dimension to the debate of the Choice Act by empirically testing a thought experiment: if the Choice Act had been controlling law from 2012 to 2016, how would the CFPB's law enforcement cases have changed? While the Choice Act includes broad structural, procedural and substantive changes to the CFPB and the laws it enforces, this thought experiment is limited to two substantive legal changes: (1) the elimination of the Dodd-Frank Act's prohibition of unfair, deceptive and abusive acts or practices and (2) the broad exemption for payday loans, car title loans, and other similar forms of small dollar lending.

\section{RESULTS}

This Part presents two categories of results: (1) results tracking the CFPB's enforcement track record through the 2016 calendar year and (2) results exploring the consequences of the Financial Choice Act of 2017.

\section{A. The CFPB's Enforcement Track Record through 2016}

${ }^{74}$ Peterson, CFPB Empirical Review, supra note 8, at 1073-76.

${ }^{75} \mathrm{Id}$. 
In 2016, the CFPB continued to maintain a brisk pace of enforcement actions with a small decline in the number of announced actions in comparison to 2015. Figure 1 provides a graphic representation of the number of public law enforcement cases announced by the CFPB juxtaposed with the number of CFPB employees by year. From 2012 through 2014, the total number of CFPB employees grew steadily as did the number of announced enforcement matters. The per-year number of cases peaked in 2015 with 55 announced matters. In 2016 the CFPB announced 42 new enforcement matters.

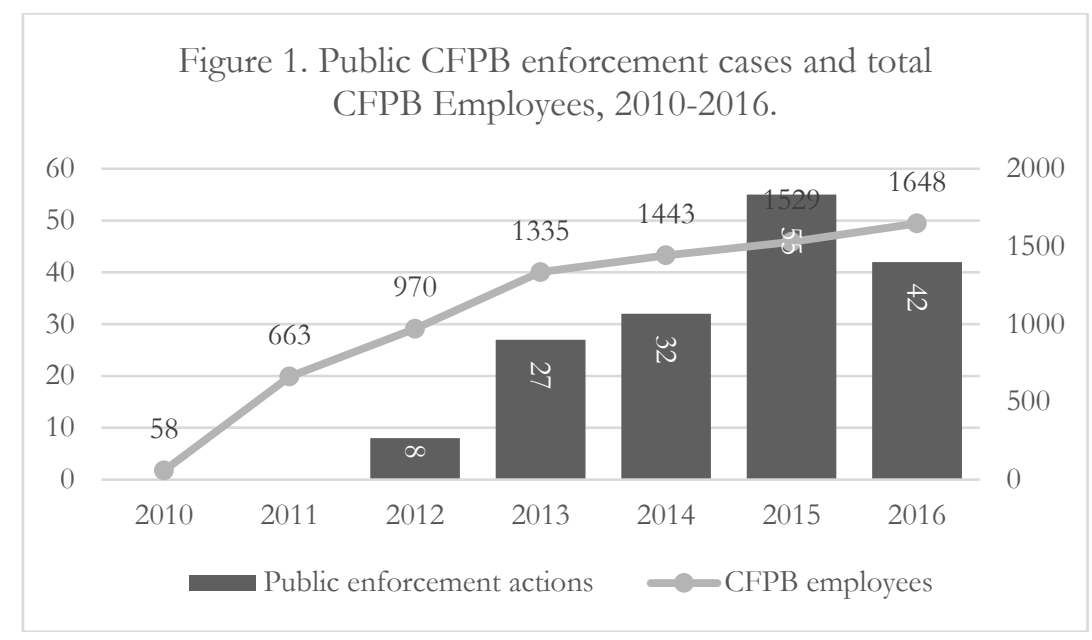

Table 1 provides further context by listing the monetary value in consumer relief and civil money penalties of public CFPB enforcement actions by year. These values are further classified by whether the consumer relief and civil money penalties were imposed upon banks, credit unions, or non-depository business. In 2016 the CFPB imposed nearly $\$ 196$ million in civil money penalties, an amount comparable to the $\$ 205$ million imposed in 2015. However, total consumer relief declined significantly from $\$ 6.5$ billion in 2015 to $\$ 292$ million in 2016. Calendar year 2016 did see the first CFPB public enforcement action against a credit union. The CFPB signed a consent order with Navy Federal Credit Union providing $\$ 23$ million in consumer relief and a $\$ 5.5$ million civil money penalty for misleading customers about its debt collection practices and unlawfully restricting consumers' access to their own funds. ${ }^{7}$ Credit Unions, only less than a half dozen of which meet the $\$ 10$ billion asset threshold for CFPB jurisdiction, have only paid about two-tenths of one percent of all consumer relief. In comparison, through 2016 the CFPB has generated approximately $\$ 7.4$ billion in consumer relief from banks and about $\$ 4$ billion in consumer relief from nondepository consumer financial services companies. http://

${ }^{76}$ In re Navy Fed. Credit Union, CFPB No. 2016-CFPB-0024 (Oct. 11, 2016), files.consumerfinance.gov/f/documents/102016_cfpb_NavyFederalConsentOrder.p df. 
Table 1. Total consumer relief and civil money penalties in public CFPB enforcement actions against banks, nonbanks, and credit unions, 2012-2016.

\begin{tabular}{|c|c|c|c|c|c|}
\hline & & \multicolumn{2}{|c|}{ Total consumer relief } & \multicolumn{2}{|c|}{ Civil money penalties } \\
\hline & & $\$$ & $\%$ & $\$$ & $\%$ \\
\hline \multirow{3}{*}{2012} & banks & $425,000,000$ & 100.0 & $46,100,000$ & 100.0 \\
\hline & nonbanks & 100,000 & 0.0 & 5,000 & 0.0 \\
\hline & total & $425,100,000$ & 100.0 & $46,105,000$ & 100.0 \\
\hline \multirow{3}{*}{2013} & banks & $485,800,000$ & 90.6 & $47,634,000$ & 63.5 \\
\hline & nonbanks & $50,539,465$ & 9.4 & $27,366,002$ & 36.5 \\
\hline & total & $536,339,465$ & 100.0 & $75,000,002$ & 100.0 \\
\hline \multirow{3}{*}{2014} & banks & $1,065,300,000$ & 27.7 & $38,700,000$ & 62.0 \\
\hline & nonbanks & $2,784,071,234$ & 72.3 & $23,736,076$ & 38.0 \\
\hline & total & $3,849,371,234$ & 100.0 & $62,436,076$ & 100.0 \\
\hline \multirow{3}{*}{2015} & banks & $5,385,059,808$ & 83.8 & $109,500,000$ & 53.5 \\
\hline & nonbanks & $1,042,537,401$ & 16.2 & $95,229,004$ & 46.5 \\
\hline & total & $6,427,597,209$ & 100.0 & $204,729,004$ & 100.0 \\
\hline \multirow{4}{*}{2016} & banks & $88,030,035$ & 30.1 & $124,130,756$ & 63.4 \\
\hline & nonbanks & $181,437,672$ & 62.0 & $66,104,001$ & 33.8 \\
\hline & credit unions & $23,000,000$ & 7.9 & $5,500,000$ & 2.8 \\
\hline & total & $292,467,707$ & 100.0 & $195,734,757$ & 100.0 \\
\hline \multirow{4}{*}{ Total } & banks & $7,449,189,843$ & 64.6 & $366,064,756$ & 62.7 \\
\hline & nonbanks & $4,058,685,772$ & 35.2 & $212,440,083$ & 36.4 \\
\hline & credit unions & $23,000,000$ & 0.2 & $5,500,000$ & 0.9 \\
\hline & total & $11,530,875,614$ & 100.0 & $584,004,839$ & 100.0 \\
\hline
\end{tabular}

Source: Analysis of publicly announced CFPB enforcement actions 2012-2016.

Table 2 shows trends in the settlement of CFPB cases alongside the CFPB's decision to charge an individual defendant in each enforcement action. With respect to the former, in 17 out of 42 enforcement actions announced in 2016, at least one defendant had not reached a settlement agreement with the Bureau. With about 40 percent of cases contested, 2016 saw a significant uptick in the proportion of cases where the CFPB had not concluded a settlement agreement at the time it announced each action. Nevertheless, nine of the 17 contested cases were relatively minor disputes that the CFPB brought as part of two "sweeps." The first was a sweep of car title lenders in Arizona that were violating the Truth in Lending Act's restriction on advertising interest rates in a format other than an annual percentage rate. ${ }^{77}$ All of the cases were settled shortly after announcement with consent to a relatively modest civil money penalty. The second sweep focused on several pawnshops in Virginia that were

7715 U.S.C. \1664(c); Press Release, CFPB, CFPB Sues Five Arizona Title Lenders for Failing to Disclose Loan Annual Percentage Rate to Consumers (September 21, 2016), https:/ /www.consumerfinance.gov/aboutus/newsroom/cfpb-sues-five-arizona-title-lenders-failing-disclose-loan-annualpercentage-rate-consumers/. 
providing consumers with inaccurate TILA price disclosures. ${ }^{78}$ Like the Arizona sweep, each case resolved quickly with a civil money penalty. Placing these matters to the side, the eight remaining contested cases reflect a level of settlement comparable to prior years.

The rate at which the CFPB charged at least one individual person in public enforcement actions declined slightly in 2016. In prior years, the CFPB included charges against at least one individual person in between 25 and 37 percent of cases. In 2016, 9 out of 42 enforcement cases included charges against an individual person reflecting a rate of about 21 percent. Whether the Bureau charges individuals in public enforcement actions is important, because a key lesson of the financial crisis was the importance of holding individual employees accountable for corporate wrongdoing. ${ }^{79}$ On the other hand, charging individual defendants decreases the likelihood of achieving a settlement and increases the resources the Bureau must dedicate to each matter. Overall the Bureau has charged an individual defendant in 28 percent of its public enforcement cases.

Table 2. Settlement, individual accountability, and deception in public CFPB enforcement actions by year, 2012-2016.

\begin{tabular}{cccccc}
\hline \hline & All cases & \multicolumn{2}{c}{$\begin{array}{c}\text { Cases contested at } \\
\text { filing }\end{array}$} & \multicolumn{2}{c}{$\begin{array}{c}\text { Cases w/ } \\
\text { individual charged }\end{array}$} \\
\cline { 2 - 6 } 2012 & $n$ & $n$ & $\%$ & $n$ & $\%$ \\
2013 & 8 & 6 & 22.2 & 8 & 37.5 \\
2014 & 32 & 11 & 34.4 & 12 & 37.5 \\
2015 & 55 & 10 & 18.2 & 14 & 25.5 \\
2016 & 42 & 17 & 40.5 & 9 & 21.4 \\
total & $\mathbf{1 6 4}$ & $\mathbf{4 6}$ & $\mathbf{2 8 . 0}$ & $\mathbf{4 6}$ & $\mathbf{2 8 . 0}$ \\
\hline Source: Analysis of publicly announced CFPB enforcement actions, 2012- & \multicolumn{4}{c}{} \\
\hline \hline
\end{tabular}

In the years following passage of the Dodd-Frank Act, the legal theory that generated the most discussion and controversy was the prohibition of "abusive" practices, an addition to the longer-standing restrictions on deceptive and unfair conduct. Some have expressed concern that a general prohibition of abusive practices would allow the CFPB to use an 'I know it when I see it' approach to enforcement that

7815 U.S.C. \1607(a)(6); Press Release, CFPB, CFPB Takes Action Against Pawn Companies for Deceiving Consumers About Loan Costs (December 19, 2016), https://www.consumerfinance.gov/about-us/newsroom/cfpb-takes-action-againstpawn-companies-deceiving-consumers-about-loan-costs/.

79. U.S. FIN. CRISIS INQUIRY COMM'N, supra note 6, at xix. See also Emily Stephenson, U.S. Consumer Watchdog Says Committed to Stiff Penalties, REUTERS (Oct. 23, 2013), http://www.reuters.com/article/us-washington-summit-cordrayidUSBRE99M1K520131023 (statement of Richard Cordray) ('I've always felt strongly that you can't only go after companies. Companies run through individuals, and individuals need to know that they're at risk when they do bad things under the umbrella of a company."). 
could lead to abuse of government power. ${ }^{80}$ Table 3 provides an interesting contrast between CFPB cases that included deceptive practices claims and cases that included abusive practices claims. In every year of the CFPB's existence the number and size of cases attacking false or misleading claims far outstrips those cases challenging abusive practices. Reflecting trends of previous years, in 2016 a majority of all CFPB cases (23 out of 42) included at least one claim challenging false or misleading material statements made by a bank, credit union, or financial service provider. Moreover, the largest CFPB cases as measured by relief provided to American consumers have overwhelmingly included claims attacking deceptive practices. In the history of the CFPB, over 93 percent of all consumer relief was awarded in cases where the business deceived its customers about a material fact. In contrast, the CFPB has accused businesses of engaging in abusive practices relatively infrequently and only in relatively small cases. Overall, consumer relief in cases alleging abusive practices constituted only around 1 percent of all consumer relief awarded in CFPB enforcement actions. Indeed, these data suggest that above all else, the CFPB's enforcement program has focused on promoting truthfulness in consumer finance.

Table 3. Deceptive practices vs. abusive practices in public CFPB enforcement cases, 2012-2016.

\begin{tabular}{ccccccccc}
\hline \hline & \multicolumn{3}{c}{ Cases pleading deceptive practices } & \multicolumn{3}{c}{ Cases pleading abusive practices } \\
\cline { 2 - 9 } & $n$ & $\%$ & $\begin{array}{c}\text { consumer relief \$ } \\
\times 1000^{*}\end{array}$ & $\%$ & $n$ & $\%$ & $\begin{array}{c}\text { consumer relief \$ } \\
\times 1000^{*}\end{array}$ & $\%$ \\
\cline { 2 - 9 } 2012 & 7 & 87.5 & $437,058.0$ & 97.44 & 0 & 0.0 & .0 & 0.00 \\
2013 & 12 & 44.4 & $2,372,481.7$ & 84.56 & 2 & 7.4 & 499.2 & 0.02 \\
2014 & 18 & 56.3 & $2,154,125.0$ & 94.74 & 5 & 15.6 & $99,529.1$ & 4.38 \\
2015 & 37 & 67.3 & $5,784,886.5$ & 96.58 & 8 & 14.5 & $20,778.0$ & 0.35 \\
2016 & 23 & 54.8 & $127,379.2$ & 79.98 & 7 & 16.7 & $3,103.1$ & 1.95 \\
total & $\mathbf{9 7}$ & $\mathbf{5 9 . 1}$ & $\mathbf{1 0 , 8 7 5 , 9 3 0 . 4}$ & $\mathbf{9 3 . 1 4}$ & $\mathbf{2 2}$ & $\mathbf{1 3 . 4}$ & $\mathbf{1 2 3 , 9 0 9 . 5}$ & $\mathbf{1 . 0 6}$ \\
\hline
\end{tabular}

*'Total consumer relief figures reflect awards generated in cases that included each type of enumerated statutory claim. However, monetary awards may be attributable to multiple violations of different laws asserted in each case. Year of award calculations are based on the date first filing in each case and include cases first announced by December 31, 2016 with final consumer relief awarded prior to July 1, 2017. Source: Analysis of publicly announced CFPB enforcement actions, 2012-2016.

\section{B. Understanding the Financial Choice Act of 2017 through the Lens of Past CFPB Enforcement Actions}

The CFPB's track record of focusing on correcting deceptive financial practices contrasts sharply with the proposed Financial Choice Act of 2017. Table 4 presents data on how sections 733, 734, and 735 of the Choice Act would have affected the CFPB's enforcement track record if these sections had been controlling law at the time

${ }^{80}$ Reginald R. Goeke, Is the CFPB Torturing Language with Its Abusive Standard?, LAw360 (Feb. 12, 2015, 5:41 PM), http://www.law360.com/articles/621386/is-thecfpb-torturing-language-with-its-abusive-standard-?article_related_content $=1$ ("This 'I know it when I see it' approach naturally grants the CFPB the maximum flexibility to bring enforcement actions, while granting industry participants the minimum level of notice about what is required of them.").

\section{- Working Draft•}


of each case. Section 733 would eliminate regulatory and enforcement jurisdiction over payday loans, car title loans, and other similar forms of small dollar credit. ${ }^{81}$ Section 734 would repeal the Dodd-Frank Act's prohibition of deceptive, unfair, and abusive consumer finance. ${ }^{82}$ Looking back at CFPB enforcement actions, those cases that only pleaded UDAAP claims would not have been possible if section 734 of the Choice Act were in effect. Similarly, every CFPB case involving payday or automobile title lending would have been untenable if section 733 were controlling law. The effect of these two changes is tallied for a selected list of product or service types in Table 4. Notably, 13 of the CFPB's 52 mortgage cases only included UDAAP charges and therefore would have been eliminated. Forty-one percent of debt collection cases would have been eliminated and 63 percent of credit card cases would have been impossible. And of course, all 24 of the CFPB's payday lending related cases would have been unviable if section 733 of the Choice Act had been controlling law at the time of each case. Indeed, a large proportion of the CFPB's cases in virtually every type of financial product or service would have been impossible if the Choice Act had been in effect from 2012 to 2016.

Nevertheless, focusing on eliminated cases actually understates the effect the Choice Act would have had upon the CFPB's track record. In addition to eliminated cases, the right-hand columns in table 4 adds those cases that would have been seriously weakened by the Choice Act for one or more of three reasons. First the right-hand columns include those cases where at least one UDAAP claim would have been eliminated under section 733 but one or more claims under an enumerated statute would have remained. Many CFPB cases include both UDAAP claims as well as one or more causes of action arising out of an enumerated statute such as the Truth in Lending Act or the Fair Debt Collection Practices Act. However, violations that sound in UDAAP law are often more serious and associated with more consumer harm than what are sometimes technical violations of enumerated statutes. The elimination of UDAAP jurisdiction would seriously weaken these enforcement actions. Second, the right-hand columns include cases some courts might have considered to be beyond CFPB jurisdiction because they involved a form of small dollar credit similar to payday loans. While section 733 of the Choice Act provides an exemption to "payday loans, vehicle title loans, or other similar loans," the Act does not provide guidance on what types of credit are "similar" to payday loans. Arguably, defendants in pawn shop cases and some forms of installment lending cases could claim they too qualify for the Choice Act's small dollar lending exemption. These cases would have been severely weakened by the Choice Act because the CFPBs jurisdiction to would have been unclear. And third, the right-hand columns also add cases that included Equal Credit Opportunity Act claims, which would have been undermined by repeal of the CFPB's guidance on racial discrimination in automobile finance in section 735 of the Choice Act. ${ }^{83}$ With an explicit rebuke from Congress, the authority of the CFPB to challenge auto finance company kick-backs to car dealers in exchange for delivering above par interest rate loans to Black and Latino borrowers would have been much less certain.

With the notable exception of mortgage lending cases arising under the Real Estate Settlement Procedures Act, ${ }^{84}$ the combined effect of sections 733, 734 and 735 of the

${ }^{81}$ H.R. $10 \int 733$ (2017).

${ }^{82}$ H.R. $10 \int 734$ (2017).

${ }^{83} \mathrm{Id}$. at $\int 735$.

${ }^{84}$ Real Estate Settlement Procedures Act of 1974, Pub. L. No. 93-533, 88 Stat.

1724 (codified as amended at 12 U.S.C. ch. 27).

\section{- Working Draft•}


Choice Act would have been to eliminate or severely weaken almost every CFPB enforcement case. If the Choice Act had been in effect, every single CFPB enforcement action involving credit cards, payday loans, ancillary "add-on" products, debt relief services, automobile financing, student loans, payment processing, checking or savings accounts, and pawnshops would have either been eliminated or substantially weakened. The Choice Act would also have eliminated or seriously weakened 38 out of 39 debt collection cases and four out of five retail finance cases.

Table 4. CFPB Enforcement Actions from 2012-2016 that would have been eliminated or weakened under the Financial Choice Act of 2017 by affected financial product or service.

\begin{tabular}{lccccc}
\hline \hline \multirow{2}{*}{$\begin{array}{c}\text { Financial product } \\
\text { or service }\end{array}$} & $\begin{array}{c}\text { Actual } \\
\text { CFPB } \\
\text { cases }\end{array}$ & $n$ & Cases eliminated & \multicolumn{2}{c}{$\begin{array}{c}\text { Cases eliminated or } \\
\text { seriously weakened }\end{array}$} \\
\cline { 3 - 6 } Mortgages & 52 & 13 & $25.0 \%$ & 22 & $\%$ \\
Debt collection & 39 & 16 & $41.0 \%$ & 38 & $42.3 \%$ \\
Credit cards & 27 & 17 & $63.0 \%$ & 27 & $107.4 \%$ \\
Payday/auto title & 24 & 24 & $100.0 \%$ & 24 & $100.0 \%$ \\
Ancillary products & 18 & 13 & $72.2 \%$ & 18 & $100.0 \%$ \\
Debt relief services & 16 & 12 & $75.0 \%$ & 16 & $100.0 \%$ \\
Auto finance & 12 & 3 & $25.0 \%$ & 12 & $100.0 \%$ \\
Student loans & 10 & 3 & $30.0 \%$ & 10 & $100.0 \%$ \\
Payment processing & 9 & 8 & $88.9 \%$ & 9 & $100.0 \%$ \\
Deposit accounts & 6 & 3 & $50.0 \%$ & 6 & $100.0 \%$ \\
Retail finance & 5 & 2 & $40.0 \%$ & 4 & $80.0 \%$ \\
Pawn loans & 5 & 0 & $0.0 \%$ & 5 & $100.0 \%$ \\
Remittances & 0 & 0 & $\mathrm{n} / \mathrm{a}$ & 0 & $\mathrm{n} / \mathrm{a}$ \\
\hline
\end{tabular}

Source: Analysis of Financial Choice Act of 2017, H.R. 10 S $733,734,735$ in relation to public CFPB

Enforcement Actions, 2012-2016.

Placing to the side those cases that the Choice Act merely would have weakened, the Choice Act would have entirely eliminated those CFPB cases that provided the vast majority of actual relief to American consumers. Table 5 tallies the consumer restitution, forgiven debts, and other direct consumer relief provided to the American public in CFPB cases that either exclusively pleaded UDAAP claims or involved payday lending. While the Choice Act would not have explicitly prohibited 75 percent of the CFPB's mortgage lending cases, the 25 percent of those cases that would have been eliminated generated 91.5 percent of the relief provided to consumers. Similarly, the $41 \%$ of debt collection cases eliminated by the Choice Act accounted for $87 \%$ of the relief provided to the public. Furthermore, the seventeen eliminated credit card cases were responsible for providing $\$ 6.7$ billion in relief to consumers, accounting for 94 percent of the compensation to the public for illegal practices associated with that type of product. Across every type of financial service, the Choice Act's elimination of UDAAP claims - especially those claims attacking deceptive practices-would have

\section{- Working Draft•}


protected those consumer finance businesses that the CFPB found to have caused the most harm to the largest number of Americans.

Table 5. Consumer Relief in 2012-2016 public CFPB enforcement actions that would have been eliminated under the Financial Choice Act of 2017 by affected financial product or service.

\begin{tabular}{|c|c|c|c|}
\hline \multirow{2}{*}{$\begin{array}{l}\text { Financial product } \\
\text { or service }\end{array}$} & \multirow{2}{*}{$\begin{array}{c}\text { Consumer relief } \\
\text { in actual CFPB } \\
\text { cases }\end{array}$} & \multicolumn{2}{|c|}{$\begin{array}{c}\text { Effect of cases eliminated by } \\
\text { the Choice Act }\end{array}$} \\
\hline & & $\begin{array}{l}\text { Eliminated } \\
\text { consumer relief }\end{array}$ & $\begin{array}{c}\% \\
\text { change }\end{array}$ \\
\hline Mortgages & $\$ 2,960,370,784$ & $-\$ 2,709,055,737$ & $-91.5 \%$ \\
\hline Debt collection & $\$ 6,791,303,658$ & $-\$ 5,935,777,783$ & $-87.4 \%$ \\
\hline Credit cards & $\$ 7,170,024,170$ & $-\$ 6,763,754,170$ & $-94.3 \%$ \\
\hline Payday/auto title & $\$ 73,235,927$ & $-\$ 73,235,927$ & $-100.0 \%$ \\
\hline Ancillary products & $\$ 2,453,511,025$ & $-\$ 2,165,111,025$ & $-88.2 \%$ \\
\hline Debt relief services & $\$ 298,590,242$ & $-\$ 257,375,522$ & $-86.2 \%$ \\
\hline Auto finance & $\$ 197,487,783$ & $-\$ 49,687,783$ & $-25.2 \%$ \\
\hline Student loans & $\$ 525,480,184$ & $-\$ 23,870,184$ & $-4.5 \%$ \\
\hline Payment processing & $\$ 144,164,150$ & $-\$ 144,164,150$ & $-100.0 \%$ \\
\hline Deposit accounts & $\$ 88,303,145$ & $-\$ 36,403,145$ & $-41.2 \%$ \\
\hline Retail finance & $\$ 95,579,124$ & $-\$ 1,050,000$ & $-1.1 \%$ \\
\hline Pawn loans & $\$ 0$ & $\$ 0$ & $\mathrm{n} / \mathrm{a}$ \\
\hline Remittances & $\$ 0$ & $\$ 0$ & $\mathrm{n} / \mathrm{a}$ \\
\hline \multicolumn{4}{|c|}{$\begin{array}{r}\text { Source: Analysis of Financial Choice Act of 2017, H.R. } 10 \iiint_{3} 733,735 \text { in relation to } \\
\text { Public CFPB Enforcement Actions, 2012-2016.This table attributes awarded consumer } \\
\text { relief to multiple product or service classifications for cases relating to more than one } \\
\text { type of product or service and includes cases announced by December 31, } 2016 \text { with final } \\
\text { consumer relief awarded prior to July 1, } 2017 .\end{array}$} \\
\hline
\end{tabular}

Similarly, Table 6 shows the effect the proposed elimination of UDAAP authority and payday lending jurisdiction would have had on civil money penalties imposed by the CFPB from 2012 to 2016. Similar to the effect of the Choice Act upon consumer relief, had the proposed legislation been in effect, it would have vastly reduced the fines the CFPB imposed on companies that engaged in unfair, deceptive, or abusive practices. For example, those cases accounting for nearly 95 percent of the civil money penalties imposed by the CFPB relating to credit cards would have been eliminated. Moreover, the Choice Act would have wiped out all of the fines related to payment processing and deposit accounts. Most notably, in 2016 the CFPB imposed a $\$ 100$ million fine on Wells Fargo for fraudulently creating over two million fake, unauthorized bank accounts in the names of its customers. The CFPB challenged this practice using the UDAAP authority that the Choice Act proposes to eliminate. 
Table 6. Civil Money Penalties in 2012-2016 CFPB Enforcement Actions that Would Have Been Eliminated Under the Financial Choice Act of 2017 by Effected Financial Product or Service.

\begin{tabular}{|c|c|c|c|}
\hline \multirow{2}{*}{$\begin{array}{c}\text { Financial product } \\
\text { or service }\end{array}$} & \multirow{2}{*}{$\begin{array}{c}\text { CMPs in } \\
\text { actual } \\
\text { CFPB cases }\end{array}$} & \multicolumn{2}{|c|}{$\begin{array}{c}\text { Effect of cases eliminated } \\
\text { by the Choice Act }\end{array}$} \\
\hline & & $\begin{array}{l}\text { Eliminated } \\
\text { CMPs }\end{array}$ & $\begin{array}{c}\% \\
\text { change }\end{array}$ \\
\hline Mortgages & $\$ 124,197,759$ & $-\$ 16,213,001$ & $-13.1 \%$ \\
\hline Debt collection & $\$ 173,980,000$ & $-\$ 100,750,000$ & $-57.9 \%$ \\
\hline Credit cards & $\$ 280,700,000$ & $-\$ 266,100,000$ & $-94.8 \%$ \\
\hline Payday/auto title & $\$ 28,942,000$ & $-\$ 28,942,000$ & $-100.0 \%$ \\
\hline Ancillary products & $\$ 133,250,000$ & $-\$ 124,150,000$ & $-93.2 \%$ \\
\hline Debt relief services & $\$ 134,336,003$ & $-\$ 112,421,002$ & $-83.7 \%$ \\
\hline Auto finance & $\$ 40,465,000$ & $-\$ 5,250,000$ & $-13.0 \%$ \\
\hline Student loans & $\$ 14,175,002$ & $-\$ 8,025,001$ & $-56.6 \%$ \\
\hline Payment processing & $\$ 12,476,000$ & $-\$ 12,476,000$ & $-100.0 \%$ \\
\hline Deposit accounts & $\$ 130,700,000$ & $-\$ 113,000,000$ & $-86.5 \%$ \\
\hline Retail finance & $\$ 350,001$ & $-\$ 50,000$ & $-14.3 \%$ \\
\hline Pawn loans & $\$ 27,500$ & $\$ 0$ & $0.0 \%$ \\
\hline Remittances & $\$ 0$ & $\$ 0$ & $\mathrm{n} / \mathrm{a}$ \\
\hline \multicolumn{4}{|c|}{$\begin{array}{l}\text { Source: Analysis of Financial Choice Act of 2017, H.R. } 10 \$ \int 733 \text { and } 735 \text { in relation to } \\
\text { public CFPB Enforcement Actions, 2012-2016. This table attributes awarded civi } \\
\text { money penalties to multiple product or service classifications for cases relating to more } \\
\text { than one type of product or service and includes cases announced by December } 31 \text {, } \\
2016 \text { with final consumer relief awarded prior to July 1, 2017. }\end{array}$} \\
\hline
\end{tabular}

\section{CONCLUSION}

The Financial Choice Act of 2017 is appropriately named in at least one sense: its proposed restrictions on the authority of the Consumer Financial Protection Bureau reflect a choice by the House of Representatives to protect financial companies at the expense of consumers. This choice is borne out by the data. As this empirical review of CFPB enforcement cases demonstrates, nearly all of the relief provided to American consumers in CFPB enforcement cases arose where a bank, credit union, or other finance company deceived their customers about a material aspect of their product or service. Between 2012 and 2016, the CFPB's enforcement efforts generated $\$ 10.5$ billion in consumer relief -accounting for 93 percent of all compensation - in cases that included a deceptive-practices claim. Had the Choice Act been in effect, the CFPB would have been powerless to stop the deception of American consumers by financial corporations within its jurisdiction. This change alone would have eliminated or seriously weakened the vast majority of CFPB cases. Moreover, the Choice Act's blanket exemption on law enforcement cases involving payday loans and similar forms of credit would have eliminated at least 24 enforcement cases where the CFPB found

\section{- Working Draft•}


payday or vehicle title lenders breaking the law, generating $\$ 73$ million in consumer relief and $\$ 28$ million dollars in civil money penalties. Between the Choice Act's elimination of UDAAP claims and its proposed exemption for payday lenders, had the Act been in effect from 2012 to 2016, many consumers would have lost out on billions of dollars of relief, and even more would have fallen prey to unchecked violations of numerous consumer protection laws. This empirical comparison of the proposed Choice Act's provisions to the CFPB's law enforcement track record leaves little doubt that if the bill passes, meaningful consumer law enforcement will grind to a halt within the rebranded Consumer Law Enforcement Agency. Indeed, the Choice Act's renaming of the CFPB as the Consumer Law Enforcement Agency is ironic and misleading. The Choice Act makes a stark and unapologetic choice favoring corporate wrongdoing and lawlessness over consumers 